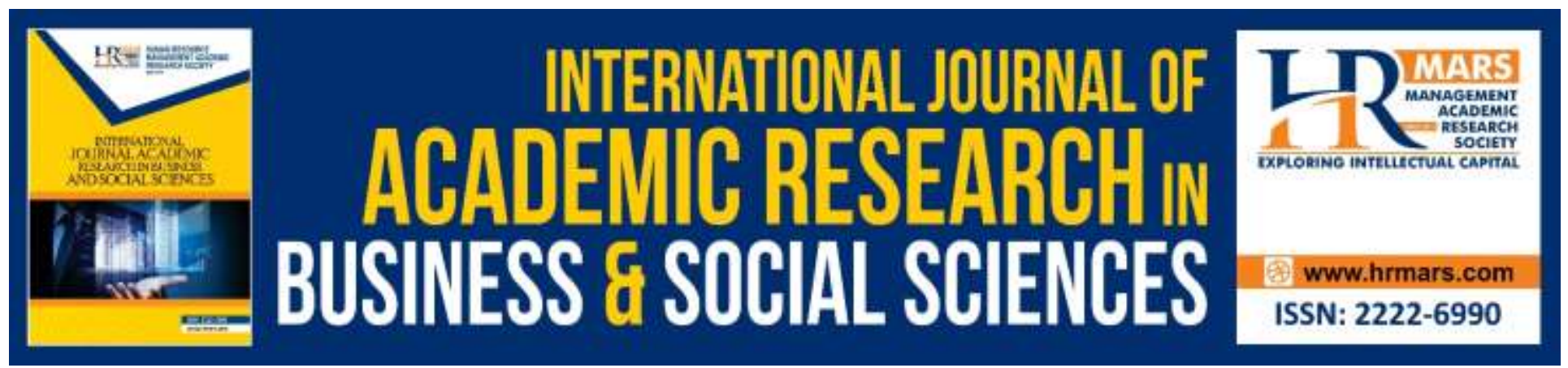

\title{
The Impact of Workplace Bullying on Employee Cynicism with Mediating Role of Psychological Contract
}

Maria Rabia Haq, Muhammad Zia-ud-Din, Shahpara Rajvi

To Link this Article: http://dx.doi.org/10.6007/IJARBSS/v8-i8/4445

DOI: $10.6007 /$ IJARBSS/v8-i8/4445

Received: 17 July 2018, Revised: 28 July 2018, Accepted: 13 August 2018

Published Online: 28 August 2018

In-Text Citation: (Haq, Zia-ud-Din, \& Rajvi, 2018)

To Cite this Article: Haq, M. R., Zia-ud-Din, M., \& Rajvi, S. (2018). The Impact of Workplace Bullying on Employee Cynicism with Mediating Role of Psychological Contract. International Journal of Academic Research in Business and Social Sciences, 8(8), 124-134.

Copyright: (C) 2018 The Author(s)

Published by Human Resource Management Academic Research Society (www.hrmars.com)

This article is published under the Creative Commons Attribution (CC BY 4.0) license. Anyone may reproduce, distribute, translate and create derivative works of this article (for both commercial and non-commercial purposes), subject to full attribution to the original publication and authors. The full terms of this license may be seen

at: http://creativecommons.org/licences/by/4.0/legalcode

Vol. 8, No. 8, August 2018, Pg. 124 - 134

http://hrmars.com/index.php/pages/detail/IJARBSS

JOURNAL HOMEPAGE

Full Terms \& Conditions of access and use can be found at http://hrmars.com/index.php/pages/detail/publication-ethics 


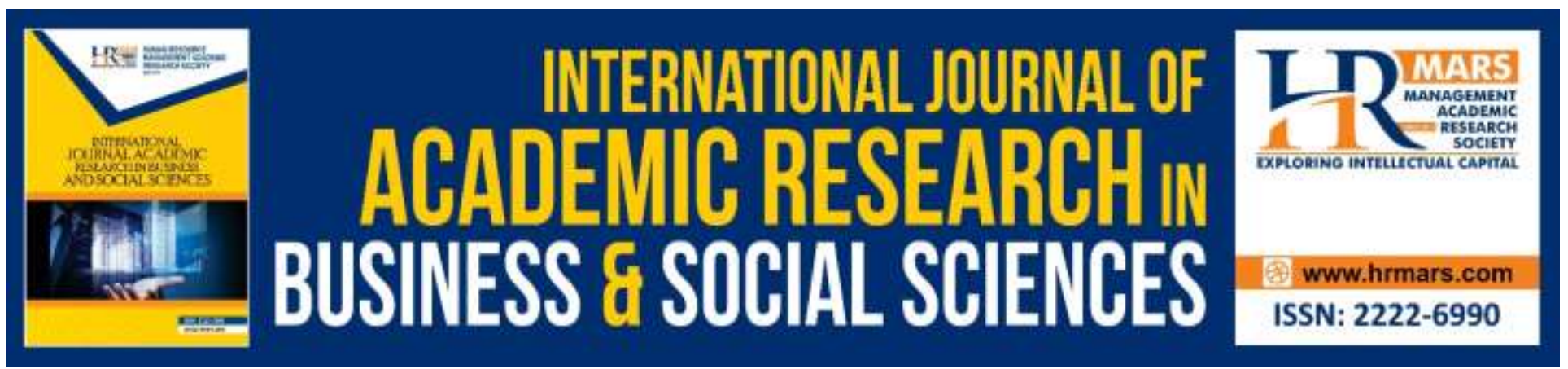

\title{
The Impact of Workplace Bullying on Employee Cynicism with Mediating Role of Psychological Contract
}

\author{
Maria Rabia Haq \\ (Corresponding Author), MPhil Scholar, Department Public Administration, Government College \\ University Faisalabad, Pakistan \\ Email: mariarabiahaq@gmail.com \\ Muhammad Zia-ud-Din \\ Lecturer, Department Public Administration, Government College University Faisalabad, Pakistan \\ Email: zeeyah4@hotmail.com \\ Shahpara Rajvi \\ MPhil Scholar, Department Public Administration, Government College University Faisalabad, \\ Pakistan \\ Email: shahpararajvi@gmail.com
}

\section{Abstract}

Workplace bullying can ground cynicism between the employees. The reason of this paper is to observe the motives of bullying and the way it can be resolved. The look at explored the effect of workplace bullying on employee's cynicism and psychological contract. facts are examined through Statistical bundle for Social Sciences (SPSS) model 24. The data comprised 150 employees working within the textile sector of Faisalabad. The results of this study showed that there is a significant relationship among workplace bullying and employee cynicism. The effects additionally suggest that the relationship among workplace bullying and employee cynicism may be in part mediated by psychological contract. This paper also offers conclusion, recommendations, and suggestions for future researchers.

Keywords: Workplace Bullying, Cynicism, Psychological Contract.

\section{Introduction}

Background

During the past 10 to 15 years there has been a lot of work done against workplace bullying in Europe and rest of the world. Workplace Bullying can be defined as persistent mistreatment at 
work place by others. Layman began to explore bullying at work in 1980 in Sweden and his work sparked active public debate. Research on workplace bullying started in early 1990 in Norway and Finland and soon after that inhabits of German, UK, Austria and Ireland also started researches on this topic (Jhosan, 2009).

Workplace relationships put an intense impact at the emotional and physical fitness of the employees (Jhosan, 2009). Bullying is a non-physical violence at workplace ,Workplace bullying has been described as constant and regular negative behavior towards an employee or its work. The studies shown that victims of this negative behavior can have psychological symptoms anxiety, sleep problems, depression, burn out or increased substance use and can result in negative job satisfaction (Escartin, 2016). In 2011 Canadian province Manitoba imposed new obligation on employees to protect workers from workplace bullying and harassment. There has been a lot of work done against workplace bullying all over the world but the work done in Pakistan over this issue is negligible.

Workplace bullying is constant harassment of one or more staff members against the other employees normally by means of negative behavior (Shehzad, 2017). It includes any regular behavior e.g. (unsightly, shameful or pointless) against any person or group of employees. The different types of bullying like person correlated and work-associated bullying may be distinguished with the aid of many research (Shehzad, 2017). Turbulent work load or inappropriate deadlines may be classified as work related bullying. while, person related bullying may be described as teasing, passing insolent comments, playing impractical jokes on different employees. workplace bullying is an imperative purpose of decrease job effective well-being and job satisfaction.

Bullying has caught the eye of scholars in organization research during past era. Scholars found disastrous results of bullying like harassment at workplace, turnover intention, low commitment, low job control, job insecurities and counter work behavior etc (Shehzad, 2017). Bullying is a major below taken into consideration phenomenon as a result of organizational climate (Quereshi, 2014).

\section{Problem Statement}

The motive of this paper is to research the effect of bullying on employees. Bullying has long been a problem with employees. Employees all over our country are victims of bullying but bullying comes in many forms, some physical and some mental. workplace bullying has distressing effect on employee's cynicism and psychological contract employees who're bullied and people who work with bullies take I'll leave extra regularly than those who aren't bullied at work. inside the mid 1990's bullying has emerged as the current situation of examine. The relation between bullying, employee's cynicism and psychological contract are not well known. (Blando, 2008) Workplace bullying occurs because of interest clashes between employees. We must combat this issue from many different angles in order to make bullies uncomfortable in their intimidation.

\section{Significance of the Study}

"Previous research has indicated that the negative results of bullying conduct in an organization consist of the lack of employee morale, a high level of absence of depression, anxiety and physical ailments, and a lower in productivity. The relationship between bullying and its impact on the employee's cynicism was studied in this paper. Data is collected to give a comprehensive summary of workplace bullying. The paper clarifies the effects of bullying on employee's psychological contract with the association. Workplace bullying is costing employees money, their health and sometime their job that's why the study on bullying is significant. This research enhances 
the body of knowledge towards bullying behavior in the organizations. This research offers benefits to the current and future era and helps the organizations to end up aware of bullying and deliver different methods to keep away from and mitigate the bullying behavior. The data from this research offers managers with an concept of the prevalence of employee abuse and the way it impacts employee cynicism.

\section{Scope of the Study}

The purpose of this research is to analyze the effect of workplace bullying at the employees and managers working in textile sector of Faisalabad. The data is collected from the employees working in textile sector through survey questionnaire. A range of research methodologies are used to explore the effects of workplace bullying. Literature review covering the issues related to workplace bullying. The consequences of this study support the organization which are suffering from bullying problem

\section{Purpose of the study}

The main aim of this study is to check the association between bullying and psychological contract, that may effect the employees beliefs. The have a look at involved a survey tool using answers from questions concerning bullying within the workplace to provide statistical information on workplace bullying, psychological contract, and employee's cynicism. The responses from the data have been used to check the consequences of bullying on employee's psychological contract and on their beliefs.

\section{Research Questions}

Following research questions can be raised on the basis of above theoretical framework

RQ1: what is the association between workplace bullying and employee cynicism in the textile sector of Faisalabad?

RQ2: what is association among employee's psychological contract and workplace bullying in textile sector of Faisalabad?

RQ3: How psychological contract mediates the association between the employee's cynicism and workplace bullying in the textile sector of Faisalabad?

\section{Objective of the Study}

Following research objectives are shaped by way of information the research questions

To analyze the association among workplace bullying and employee's cynicism.

To test the association among workplace bullying and psychological contract.

To inquire exactly how psychological contract mediates the connection between workplace bullying and employee cynicism.

To have a look at how bullying is related to employees.

\section{Literature Review}

Workplace Bullying

There is no one specific definition for bullying in the literature. In overall, according to (Namie, 2003) bullying can starts with incivility and ends with workplace violence. Mariucci and Sinatra (2009) says that there are not any exact or detail central laws that excludes workplace bullying within the literature, the important thing words that looked in descriptions consist of negative acts, unwelcome, 
INTERNATIONAL JOURNAL OF ACADEMIC RESEARCH IN BUSINESS AND SOCIAL SCIENCES

Vol. 8, No. 8, August 2018, E-ISSN: 2222-6990 @ 2018 HRMARS

supply of power, goal has difficulty protecting oneself, and feature the motive to damage the goal. The combinations of the literature examine suggest that workplace bulling is described as repetitive unwelcomed damaging act or acts (physical, verbal, or psychological intimidation), that may consist of condemnation and degradation, expected to grounds anxiety, soreness, or damage one or a couple of man or woman. Workplace bullying is knowns as repeated and nonstop act which contains inequality of energy between the casualty and the instigator and contains a component of biasness on how casualty see the bullying behavior and effect of the conduct (Einarsen, Hoel, Zapf, \& Cooper, 2003). In the past investigations of workplace bullying, the bully is known as instigator and the casualty of bully is known as target.

Aleassa and Megdadi (2014) clarify that workplace bullying and dishonest conduct that warrant intrigue is progressively all the more being distinguished as a basic issue. As people invest most energy of their workplace, hence it is vital to make the workplace environment condition additional welcoming so it will accomplish organizational effectiveness. Aside from this, there is another arrangement of conduct which is essentially unfortunate and broken and bullying is one of these practices. These practices have a negative effect on people, as well as on associations. The research paper featured a few effects of harassment in the workplace, for example, emotional harm, physical ailment and expert damage to bullying victims. These effects then again antagonistically influence the profitability, benefit, high non-attendance, psychological contract and employee cynicism. Workplace bullying is basically verbal in nature and its impact can be devastating. It adversely affects the job of the victims. Workplace bullying negatively affects the employee's and thus results in less psychological contract and employee's cynicism.

Essen (2014) explain that all organizations depend on their staff to represent their firms in the most positive and effective manner. Workplace bullying influences all levels of an association (Martino, 2003). Workplace and bullying exercises are on ascend over the Europe. There are numerous components adding to harassment and bullying at workplace which unfavorably influences the potential turnover of the association. Through different policies and rules harassment and bullying at workplace can be overcome along these lines making a friendly domain at workplace. Workplace bullying influences the physical health, as well as the psychological health of the casualty. The majority of the members announced that it has influenced their wellbeing as well as has influenced their family life. There is a connection between harassment in the workplace and mental anguish. Studies investigating the components of mental and social work in connection to mental issues, for example, stress and depression, have concentrated essentially on a set number of exposures.

Wiedmer (2011) defines bullying in the workplace as dull negative behaviour for one or more people. Examples of bullying in the workplace are: verbal abuse, offensive behavior that can be perceived as threatening or hostile and actions that prevent an employee from doing their job. The purpose of an intimidator is to intimidate another employee to endanger their work.

\section{Employee Cynicism}

Anderson and Bateman (1997) define employee cynicism as "the feelings of frustration and disillusionment as well as negative feelings toward and distrust of a person, group, ideology, social convention, or institution". This definition covers many of the resemblances in cynicism research. Dean provides the complete definition of organizational cynicism, (1998). More than twenty years back, Kantar and Mirvis (1989) stressed that workers in the modern work environment "do not trust the what their leaders says to them and trust that their organizations, if they have the chance, will 
INTERNATIONAL JOURNAL OF ACADEMIC RESEARCH IN BUSINESS AND SOCIAL SCIENCES

Vol. 8, No. 8, August 2018, E-ISSN: 2222-6990 @ 2018 HRMARS

have attracted a broad range for example, in the field of studies and management organization, employee beliefs has been broadly understood as a "psychological flaw" that requires improvement. take benefit of them". disagreement with the organizational expectation, lack of social guide and recognition, no longer having voice inside the selection-making dealing with stress and lack of communication these are the elements that have an impact on cynicism. "Cynics additionally believe that employees have low levels of important wondering competencies and aren't worth of trust or loyalty.". a few scholars believe that cynicism is a character trait or attitude in place of a life-style (Reichers, 1997).

\section{Psychological Contract}

Psychological contract is a faith in an obligation of correspondence among a worker and an association (Rousseau,1989). at the point when a man sees that commitments she or he makes commit the association to respond less, a Psychological contract rises association routinely make understood or particular guarantees to workers about future favorable circumstances. Psychological contract manages representatives experience of individual control, a discernment that they're fit to influence their future inside the association since they might be a piece of an agreement and accordingly have the ability to choose whether to play out the obligations. (shore and Tetrick,1995). Psychological contract can along these lines assume a key part in employee motivation. (Rousseau, et al 1989). In the previous 10 years the writing on the psychological contract has been extended significantly. (1989, 1995 and 2001).

\section{Theoretical Framework}

Following theoretical framework is built by studying the literature

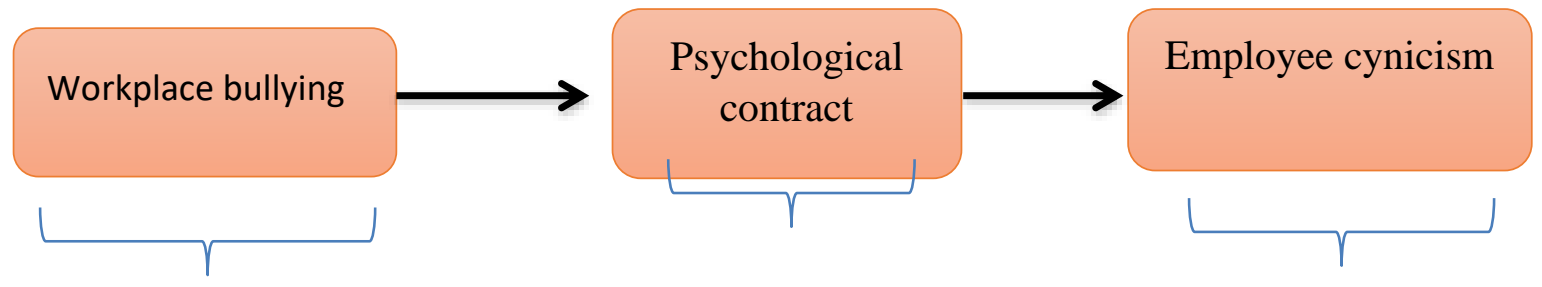

Independent

Mediating

Dependent

\section{Hypothesis}

Following hypothesis can be made by viewing the theoretical framework.

$\mathbf{H}_{1}$ : There's a significant association among workplace bullying and employee's cynicism.

$\mathbf{H}_{2}$ : There may be an association among work place bullying and psychological contract.

$\mathbf{H}_{3}$ : The connection among workplace bullying and employee's cynicism is intervened by the psychological contract.

\section{Methodology}

The character of the observe is empirical for acquiring the higher information of the effects of bullying on employees. The statistics comprised 150 employees working in the textile area of Pakistan survey-based totally questionnaire are distributed many of the employees working inside the textile area of Faisalabad. before administrating the questionnaire, all of the questions are defined to the employees.so that respondents without problems fill up the questionnaires. One 
INTERNATIONAL JOURNAL OF ACADEMIC RESEARCH IN BUSINESS AND SOCIAL SCIENCES

Vol. 8, No. 8, August 2018, E-ISSN: 2222-6990 @ 2018 HRMARS

questionnaire is given to every respondent. total 130 questionnaires are circulated among the managers and 120 are properly filled with response rate of $93.75 \%$. The respondents are selected randomly. During the distribution of the questionnaire no one individual is specially targeted. Correlation test is used to check the association between variables and to check the strength of the relationship between variables regression test is used for this purpose. SPSS version 21.0 is used for testing the hypothesis

\section{Scale and Questionnaire}

Different scales are used to measure the variables. For section one (demographics) nominal and ordinal scale is used. The instrumentality and expressiveness are workplace bullying is measured by using 22item and adopted from Negative Act Questionnaire Einarsen and Raknes (1994) The employees' cynicism is measured by using 12 items by using scale Mikkelsen (2001). Psychological contract is assessed with 17 items and adopted from Millward and Hopkins (1998). Five-point Likert scale ranging from 1-5 is used for measuring the variables.

\section{Descriptive Statistics}

Table-1. Demographics results

\begin{tabular}{llll}
\hline Variable & Scale & Frequency & Percentage \\
\hline Age & $20-25$ & 22 & 17.9 \\
& $26-30$ & 23 & 18.7 \\
& $31-35$ & 30 & 24.4 \\
& $36-40$ & 32 & 26.0 \\
Education & $41-45$ & 14 & 11.4 \\
& $56-60$ & 2 & 1.6 \\
& & & \\
& Intermediate & 29 & 87.5 \\
& Bachelor & 57 & 46.3 \\
& Master & 25 & 20.3 \\
Department & 10 & 8.1 \\
& MHD & 2 & 1.6 \\
& PHDil & 8 & 6.5 \\
& HR dep't & 32 & 26.0 \\
& Production & 23 & 18.7 \\
& Administration & 60 & 48.8 \\
\hline
\end{tabular}

Employee's working in different units of textile sector of Faisalabad are the respondents of this research.17.9\% were between the age of 20 to $25.18 .7 \%$ were between the age of 26 to 30 , and $24.4 \%$ were between the age of 31 and 35, 26.0\% were between the age of 36 to 40 and $11.4 \%$ were 41 and 45 years old and 1.6 percent were 56 and 60 years old. The mean age of the respondents was (59.9545, SD=6.95136), $87.5 \%$ Intermediate, 46.3 percent Graduation, and 20.3 percent master,8.1 percent MPhil and 1.6 percent PhD, department wise employee's $6.5 \%$ were from HR department,26.0\% from production, $18.7 \%$ from administration and $48.8 \%$ from others departments. 
INTERNATIONAL JOURNAL OF ACADEMIC RESEARCH IN BUSINESS AND SOCIAL SCIENCES

Vol. 8, No. 8, August 2018, E-ISSN: 2222-6990 C 2018 HRMARS

\section{Reliability Test}

Table shows that Cronbach's Alpha value of workplace bullying, employee cynicism and psychological contract is $.841, .765$ and .787 correspondingly. According to the above table, Cronbach's Alpha value is larger than 0.877 whhich determines the reliability of the data. If Cronbach alpha value is larger than 0.8 it means that research instruments and its results are reliable

\section{Correlation}

Above table shows that workplace bullying is significantly correlated with employee cynicism at a value of .873, which means that it is strongly significant at 1 percent. The table also explains that psychological contract is significantly related with workplace bullying at a value of .708. Employee cynicism is also significantly correlated with psychological contract at a value of .593.

\section{Regression Analysis}

\section{Model Summary}

\begin{tabular}{llllll} 
& & & & \multicolumn{3}{l}{ Std. Error of the } \\
Model & $\mathrm{R}$ & $\mathrm{R}$ Square & Adjusted R Square & Estimate & Durbin-Watson \\
\hline 1 & $.837^{\mathrm{a}}$ & .701 & .699 & .44465 & 1.668 \\
\hline
\end{tabular}

a. Predictors: (Constant), Workplace bullying

b. Dependent Variable: Employee cynicism

\section{ANOVA $^{a}$}

\begin{tabular}{llllll}
\hline Model & $\begin{array}{l}\text { Sum } \\
\text { Squares }\end{array}$ & of & Df & $\begin{array}{l}\text { Mean } \\
\text { Square }\end{array}$ & F \\
\hline Regression & 56.144 & 1 & 56.144 & 283.969 & $.000^{\mathrm{b}}$ \\
Residual & 23.923 & 121 & .198 & & \\
Total & 80.067 & 122 & & & \\
\hline
\end{tabular}

a. Dependent variable organizational cynicisms

b. Predictors: (Constant), Workplace bullying

\section{Coefficients $^{\mathrm{a}}$}

\begin{tabular}{lllllll}
\hline & & \multicolumn{2}{l}{$\begin{array}{l}\text { Unstandardized } \\
\text { Coefficients }\end{array}$} & \multicolumn{2}{l}{$\begin{array}{l}\text { Standardized } \\
\text { Coefficients }\end{array}$} \\
\multicolumn{2}{c}{ Model } & B & Std. Error & Beta & t & Sig. \\
\hline 1 & (Constant) & .841 & .172 & & 4.894 & .000 \\
& Workplace bullying & .847 & .050 & .837 & 16.851 & .000 \\
\hline
\end{tabular}


INTERNATIONAL JOURNAL OF ACADEMIC RESEARCH IN BUSINESS AND SOCIAL SCIENCES

Vol. 8, No. 8, August 2018, E-ISSN: 2222-6990 @ 2018 HRMARS

In Table R square depicts that workplace bullying has $70.1 \%$ impact on employee cynicism which shows that a significantly impact of workplace bullying on employee cynicism. To check the nature of correlation among the variables Durbin-Watson is calculated, which describes either correlation is positive, negative or zero. The value of Durbin Watson is 1.668 which is less than 2 , it depicts that there is significant positive correlation among workplace bullying bullying and employee cynicism.

$\mathrm{Y}=\mathrm{bo}+\mathrm{bX}$

Employee cynicism $=.841+.837$ (workplace bullying).

This equation shows that one-unit change in workplace bullying is increased the 1.678 units of employee cynicism.

Mediating Relation

Model Summary

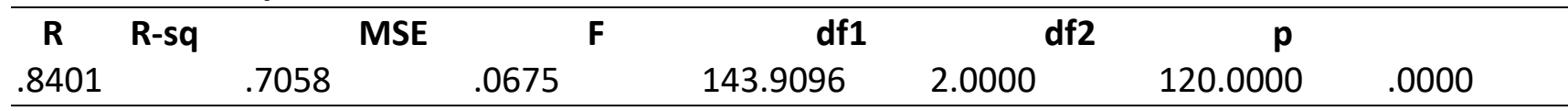

Model

\begin{tabular}{lllllll}
\hline & Coeff. & se & t & p & LLCl & ULCl \\
\hline Constant & 1.4325 & .2250 & 1.9220 & .0570 & -.0130 & .8781 \\
PC & .7977 & .0728 & 10.9507 & .0000 & .6535 & .9420 \\
WB & .0896 & .0385 & 2.3292 & .0215 & .0134 & .1657 \\
\hline
\end{tabular}

Above Tables $\mathrm{R}$ square depicts that workplace bullying and with mediator Psychological contract has $70.5 \%$ impact on employee cynicism which shows that a significantly effect of workplace bullying on employee cynicism.

$\mathrm{Y}=\mathrm{bo}+\mathrm{bX}$

Employee cynicism $=.8401+1.4325$ (workplace bullying and Psychological contract).

This equation shows that one-unit change in workplace bullying and Psychological contract is increase the 2.2726 units of employee cynicism.

\section{Future Implication and Recommendation}

No research is without some implication This research helps the organization to realize the association among workplace bullying and employee's cynicism. The correlation and regression test illustrate that workplace bullying has effect on the dependent variable employee cynicism. this study also recommends the management to reduce the level of bullying by training their supervisor and managers. This paper also give overview about how workplace bullying can affect the employee beliefs. There are some suggestions for the management to mitigate the vagueness and stress of the work. Harassment in the workplace must be examined consistently and systematically.it is the responsibility of all the organization to protect their workers from bullying. In addition, workplace bullying has an adverse effect on the organization profitability and managers in the organization need to solve this problem effectively, which can help organizations achieve their goals.

According to the current research workplace bullying can play important role in increasing employee cynicism. Though, research is not without implication. We examine the effect of workplace bullying on employee's cynicism that can be analyzed through the respondents from workers and 
INTERNATIONAL JOURNAL OF ACADEMIC RESEARCH IN BUSINESS AND SOCIAL SCIENCES

Vol. 8, No. 8, August 2018, E-ISSN: 2222-6990 @ 2018 HRMARS

managers working in the textile sector of Faisalabad, this is the one of the limitation of this study. We can examine the generalized impact or workplace bullying across the country for further studies. Furthermore, our hypothesis and theory would be beneficial to study how our results simplify to other cultural contexts. A large representative sample of employees should be used to validate the research.

\section{Conclusion}

This take a look at furthers our information of the workplace bullying -employee cynicism dating by using figuring out psychological contract as a variable that could mediate this relationship. only a few researches have seriously tested work bullying effect at the employee cynicism. the existing look at thus seeks to fill this gap in the literature. by and large, the findings on this study are consistent with beyond research. First of all, this study has reconfirmed previous studies by way of figuring out workplace bullying as a component that reasons employees cynicism. This study has recognized a significant positive correlation between workplace bullying and employee cynicism. on the other hand, and possibly more importantly, this take a look at has contributed to the studies literature by using figuring out psychological contract as a mediator affecting employee cynicism. exactly, the observe suggests that workplace bullying can weakens the trust of the employees on their organization.

\section{References}

Anderson, I. M., \& Bateman, T. S. (1997). Cynicism in the workplace: some causes and effects. Journal of organizational behavior, 18, 449-469.

Dean, J. W., Brandes, P., \& Dharwadkar, R. (1998). Organizational cynicism. academy of management review, 23(2), 341-352.

Einarsen, Hoel, Zapf, \& Cooper. (2003) bullying in the workplace: definition, prevalence, antecedents and consequences; international journal of organization theory and behavior, 13 (2), 202-248.

Einarsen, S., Raknes, B. I., \& Mathieson, S. B. (1994). Bullying and harassment at work and their relationships to work environment quality-an exploratory study. European work and organizational psychologist, 4(4), 381-401.

Johnson, S. I. (2009) international perspectives on workplace bullying among nurses: a review. international nursing review 56, 34-40

Kanter, D. I., \& Mirvis, P. (1989). The cynical Americans: living and working in an age of discontent and disillusion. san Francisco: jossey-bass.

Maureen-Dollard, Christian, D., Michelle, R., Tuckey., \& Jordi, E. (2016): Psychosocial safety climate (psc) and enacted psc for workplace bullying and psychological health problem reduction, European journal of work and organizational psychology.

Mikkelsen, E. G., \& Einarsen, S. (2001). Bullying in Danish work-life: prevalence and health correlates. European journal of work and organizational psychology, 10(4), 393-413.

Mill ward, I. J., and Hopkins, I. J. (1998), "Psychological contracts, organizational and job commitment", journal of applied psychology, vol. 28, issue 16, pp. 1530-1556.

Namie, G. (2003). Workplace bullying: escalated incivility. Ivey business journal, 88, 1- 6.

Reichers, \& Austin, J. T. (1997). Understanding and managing cynicism about organizational change. academy of management executive, 11(1), 48-59. 
INTERNATIONAL JOURNAL OF ACADEMIC RESEARCH IN BUSINESS AND SOCIAL SCIENCES

Vol. 8, No. 8, August 2018, E-ISSN: 2222-6990 @ 2018 HRMARS

Rousseau, D. (1989). psychological and implicit contracts in organizations. employee responsibilities and rights journal, 2, 121-139.

Rousseau, D. (1995). Psychological contracts in organizations: understanding the written and unwritten agreements. London: sage.

Rousseau, D. (1998). The 'problem' of the psychological contract considered. journal of organizational behaviour, 19, 665-672.

Rousseau, D. (2001). Schema, promises and mutuality: the building blocks of the psychological contract. journal of occupational and organizational psychology, 74, 511-542. 